\title{
Duties in Permanent Sovereignty over Natural Wealth and Resources and Petroleum Development in Nigeria: Towards Efficient Government Institutions and Greater Social Responsibility in the Country
}

\author{
Edward T. Bristol-Alagbariya \\ Associate Dean \& Senior Multidisciplinary Lecturer, Faculty of Law, University of Port Harcourt, NIGERIA; \\ and Visiting Research Fellow, Centre for Energy, Petroleum \& Mineral Law and Policy (CEPMLP), Graduate \\ School of Natural Resources Law, Policy \& Management, University of Dundee, Scotland, UNITED \\ KINGDOM.
}

\begin{abstract}
A previous study of the author on the need to domesticate benchmarked international standards and practices associated with Permanent Sovereignty over Natural Wealth and Resources (PSNWR) in Nigeria, in the course of petroleum and other extractive industrial operations, as aspects of PSNWR, ended by stating that a follow-up study would be embarked upon. That follow-up study would, on the premise of actual performances and/or performance indicators of relevant government institutions established on the basis of their respective enabling laws, examine the efficacy of these institutions and overall government social responsibility (GSR) associated with petroleum development in the country. From the background of global and other benchmarked international sustainable development-oriented regulatory standards and practices and existing Nigerian legal and institutional frameworks associated with PSNWR, the study evaluates the effectiveness of laws and government institutions in the context of the significant and inevitable roles of governments, in the course of petroleum development in Nigeria.

Keywords: Permanent Sovereignty over Natural Wealth and Resources (PSNWR), Petroleum Development Operations, Government Social Responsibility (GSR), Good Governance (GG) and Sustainable Development (SD).

DOI: $10.7176 / \mathrm{JLPG} / 92-08$

Publication date: December $31^{\text {st }} 2019$

\section{Introduction}

Permanent Sovereignty over Natural Resources (PSNWR) a soft law principle, which is enshrined in the UN General Assembly (UNGA) Resolution 1803 (XVII) of 14 December, 1962, entitled: 'Permanent Sovereignty over Natural Resources'. ${ }^{1}$ This principle evolved as an international political claim and a principle of international law, which is rooted in international human rights law and the principles of self-determination and economic sovereignty, and eventually became an aspect of domestic policy, law, regulatory process and practice in developing countries, which are richly endowed with major natural resources. PSNWR presupposes absolute, inalienable, free and full right of a newly independent developing country over its natural wealth and resources. ${ }^{2}$ It advocates and supports the unfettered sovereign right of resources-rich developing countries to explore and exploit their natural resources and to manage the wealth accruing from the exploitation of these resources for development of such countries and the wellbeing of their citizens, especially the wellbeing of the citizens from whose communities the resources are being exploited and/or developed for the benefit of the countries. ${ }^{3}$ So, PSNWR, vigorously advocated and promoted by developing countries in the UN system, stipulates the rights and corresponding duties of states, particularly resources-rich developing countries, over their natural resources and the management of the wealth accruing therefrom to these countries. ${ }^{4}$

However, resources-rich developing countries, especially those plagued by the resource-curse like Nigeria often promptly exercise their rights of PSNWR to exploit natural resources of their countries and to manage the wealth accruing from the exploitation of these resources, without equally performing their duties to cater for the wellbeing of their countries and citizens, including the wellbeing of their geographical regions where the natural resources being so exploited are derived, regardless of the fact that rights and duties are related and cannot be

\footnotetext{
${ }^{1}$ Office of the United Nations High Commissioner for Human Rights (UN OHCHR), 'General Assembly Resolution 1803 (XVII) of 14 December 1962, 'Permanent Sovereignty over

${ }^{2}$ N. Schrijver, Sovereignty over Natural Resources: Balancing Rights and Duties (Cambridge University Press 1997), 1-3.

${ }^{3}$ UN OHCHR, 'General Assembly Resolution 1803 (XVII) of 14 December 1962, 'Permanent Sovereignty over Natural Resources'(n1).

${ }^{4}$ UN OHCHR, 'General Assembly Resolution 1803 (XVII) of 14 December 1962, 'Permanent Sovereignty over Natural Resources'(n1); Article 1, UNGA Resolution on PSNWR; H. T. Terry, 'Legal Duties and Rights' [1903] 12 (4) The Yale Law Journal, 185-212; D. Lyons, 'The Correlativity of Rights and Duties' [1970] 4 (1) Noûs, 45-55.
} Resources'<https://www.ohchr.org/EN/ProfessionalInterest/pages/NaturalResources.aspx $>$ Accessed 29 November, 2019.
\end{abstract}


separated from each other. Hence, this follow-up study to a previous work on the need to domesticate benchmarked international standards and practices in Nigeria in the course of petroleum and other extractive industries development operations (EIOs), as aspects of PSNWR in Nigeria, would, on the premise of actual performances and/or performance indicators of relevant government institutions established on the basis of their enabling laws, examine the efficacy of these institutions and overall government social responsibility (GSR) designed to fulfil Nigeria's duties ingrained in PSNWR in the context of petroleum development in the country.

\subsection{PSNWR: Relevant Laws and Evaluation of Performances of Related Government Institutions}

The earlier research, which precedes this study, entitled 'Duties in Permanent Sovereignty over Natural Wealth and Resources and Petroleum Development in Nigeria: Need to Domesticate Benchmarked International Standards and Practices in the Country', has already indicated the importance of laws and institutions towards the development, growth, public good and overall prosperity of society, which includes global sovereign states, particularly Nigeria. ${ }^{1}$ Thus, more than identifying the laws and institutions that are associated with the duties of Nigeria inherent in PSNWR, in the context of petroleum development in the country, this study will proceed to briefly evaluate the effectiveness of laws in relation to the rule of law in Nigeria, and the effectiveness of the government institutions established by virtue of their respective enabling laws towards achieving the objectives of establishing them, subject to the duties of Nigeria, represented by its governments, inherent in PSNWR and thus petroleum development in the country. It may therefore be pertinent to consider the effectiveness of laws in relation to the rule of law in Nigeria, before proceeding to evaluate the efficacy of relevant government institutions associated with petroleum development in the country in the context of PSNWR.

\subsection{Effectiveness of Laws in Nigeria}

To consider the effectiveness of laws in Nigeria calls for an on-the-spot assessment of the rule of law in the country. The rule of law means the supremacy and observance of civil laws, which are reasonably justifiable in a democratic society, as opposed to any form of arbitrary law, authority, might or power, ${ }^{2}$ such as irrationality, unfettered prerogative and wide discretionary powers, being exercised by government functionaries in the course of governance. ${ }^{3}$ To uphold the rule of law in Nigeria means to embark on actions and/or activities in accordance with law, respect for decisions of the law courts, government or governance according to civil law and operation of a constitutional and democratic system of government in the country. ${ }^{4}$

Civilisation may be considered to mean the acceptance and observance of the rule of law, contrary to which law, due process, order, peace, stability and progress would be undermined, and civilisation would be so endangered. ${ }^{5}$ Upholding the rule of law is thus in the interest of global sovereign states such as Nigeria, as well as the overall interest of the wellbeing of humanity and society at large. ${ }^{6}$ The rule of law in Nigeria is however being undermined by ineffective implementation of laws, along with their accompanying developmental policies, plans and programmes (including projects [PPPs]), by government institutions and government functionaries, especially due to unfettered discretions and other forms of social irresponsibility of functionaries of the executive arm of government, to the detriment of the citizenry and overall public good in the country. ${ }^{7}$

\subsection{PSNWR: Evaluation of Relevant Nigerian Government Institutions}

Based on the limited scope of this study and the fact that the global and other international legal instruments indicated in the previous study only have persuasive effects on Nigeria, this subheading would concentrate on examining international institutions associated with Nigeria and other institutions that are entirely Nigeria's (domestic) institutions, in the context of PSNWR in relation to petroleum development in Nigeria.

\footnotetext{
${ }^{1}$ Goal 16, UN Sustainable Development Goals (UNSDGs) captioned 'Peace, Justice and Strong Institutions'; Public Sector Group Poverty Reduction and Economic Management (PREM) Network, Reforming Public Institutions and Strengthening Governance (The International Bank for Reconstruction and Development [IBRD]/The World Bank 2000); J. Walsh, 'How Power and Institutions Affect Development' $<$ https://www.weforum.org/agenda/2015/03/how-power-and-institutions-affect-development/> Accessed 29 November, 2019; B. Parks et al, 'Future Development: Why developing countries get stuck with weak institutions and how foreign actors can help' $<$ https://www.brookings.edu/blog/future-development/2017/07/26/why-developing-countries-get-stuck-with-weak-institutions-and-howforeign-actors-can-help/> Accessed 29 November, 2019; V. E. Dike, 'Governance and Nigeria's Weak Institutions: Is the 2020 Project Achievable?'<http://www.gamji.com/article8000/NEWS8396.htm> Accessed 29 November, 2019.

${ }^{2}$ E. Malemi, The Nigerian Constitutional Law (Princeton Publishing Co. 2012) 107-108; I. Udofia, Nigerian Constitutional Law: A Comparative Approach (Esquire Publishers 2018) 31.

${ }^{3}$ Military Governor of Lagos State v Ojukwu [1986] 1 NWLR (Pt. 18), 621 SC at 638; I. Udofia (n6) 31.

${ }^{4}$ E. Malemi (n6) 107-153; I. Udofia (n6) 31-33.

${ }^{5}$ M. Okilo, Art of Government and the Okilo Administration (Riverside Communications 1992) 1.

${ }^{6}$ C/f A. M. Samaha, 'Undue Process' [2006] 59 (3) Stanford Law Review, 601-672, especially 601 and 672; World Commission on Environment and Development (WCED), Our Common Future (Oxford University Press 1987); J. F. Sachs, The Age of Sustainable Development (University of Columbia Press 2015).

${ }^{7}$ AG Federation $v$ The Nigerian Bar Association, Lagos and Ikeja (1992), per Hon. Justice Adeyinka (of the Lagos High Court); African Guardian newspaper report, 13 July, 1992, 16; per Ag. Hon. CJ Allagoa in Minire Amakiri v Ralf Iwowari [1974] 1 Rivers State Law Report (RSLR) 1 and 5; E. Malemi (n6) 107-121.
} 


\subsubsection{The African Commission on Human and Peoples' Rights and the African Court on Human and Peoples' Rights, as Institutional Frameworks of the ACHPR and the ACHPR (Ratification and Enforcement) Act}

As already stated in the preceding study to this work, the African Commission on Human and Peoples' Rights is simply called the 'African Commission', while the African Court on Human and Peoples' Rights is simply called the 'African Court'. The ACHPR (Ratification and Enforcement) Act has more robust provisions on human rights than the provisions of the 1999 Constitution of the Federal Republic of Nigeria (CFRN) (as amended) on these rights, although it is a subsidiary law to the 1999 CFRN (as amended). Consequently, the provisions of the CFRN on human rights would prevail instead of the provisions of the ACHPR (Ratification and Enforcement) Act, given the hierarchical nature of the application and enforcement of domestic laws in Nigeria.

Based on the vibrant provisions of the ACHPR (Ratification and Enforcement) Act, there are certain human rights duties associated with it that are obligatory on Nigeria, represented by governments in the country, and these duties are by extension basically the same as the human rights duties that are inherent in PSNWR, in the context of petroleum development in the country. Thus, in the case of Social and Economic Rights Action Center (SERAC) and Centre for Economic and Social Rights (CESR) v Nigeria (otherwise called The Social and Economic Rights Case (2001), ${ }^{1}$ the African Commission, having its headquarters located in Banjul, Gambia, held that the Nigerian government was in breach of its obligations under the ACHPR by aligning with the Shell Petroleum Development Company of Nigeria Limited (SPDC/Shell Nigeria) to violate the social and economic rights of the Ogoni people. Also, there are other human rights cases that the African Court, sitting at its headquarters located in Arusha, Tanzania, has addressed, while acting on its jurisdiction, be it contentious or advisory. ${ }^{2}$

In Nigeria, the major institutions involved in the promotion, protection and enforcement of human rights include the National Human Rights Commission (NHRC), the Public Complaints Commission (PCC) and Truth and Reconciliation Commission. ${ }^{3}$ Whereas, the existence of NHRC and PCC is permanent in nature, various other government commissions of inquiry, such as the Truth and Reconciliation Commission, headed by Hon Justice Kayode Eso (JSC), which was set-up on November 29, 2007, by the Governor of Rivers State, Rt Hon. Chibuike Rotimi Amaechi, are ad hoc commissions. ${ }^{4}$ Accordingly, the preceding study to this work discusses the $\mathrm{NHRC}$, as one of the human rights institutions in Nigeria.

By and large, the implementation process of the ACHPR is weak. This is mainly because the African Commission, which is a quasi-judicial body, but main regulator and principal engineering force, that monitors the implementation of the ACHPR, only makes recommendations, which are merely advisory or persuasive on parties to disputes. ${ }^{5}$ Again, there is lack of enforceable mechanisms in African countries to enforce the decisions of the Commission on these countries and member-states of the African Union (AU). ${ }^{6}$ Any unenforceable decision lacks real potency, except that it may arouse international awareness on breach of human rights associated with such a decision. ${ }^{7}$ Furthermore, there is disconnection between the decisions, pronouncements and recommendations of the African Commission and the corresponding obligations upon AU member-states affected by such decisions, pronouncements and recommendations. Worse still, the main handicap, problem or challenge is the lack of enforceable mechanisms of the decisions of the Commission on AU member-states. This lack of enforceable mechanisms suggests or even amounts to the absence of the political will and/or essential and necessary commitment of African countries concerning human rights abuses and violations in their respective jurisdictions. ${ }^{8}$ The African Court may thus be considered a toothless bull-dog, as it only complements and reinforces the functions of the African Commission.

\footnotetext{
${ }^{1}$ Social and Economic Rights Action Center (SERAC) and Centre for Economic and Social Rights (CESR) v Nigeria, Communication $155 / 96$ [2001] ACHPR 60 (15 th Annual Activity Report); N. S. Okogbule, Globalisation and Human Rights in Africa (Sibon Books 2012 ) 217 and 237.

${ }^{2}$ In the Matter of: Request for Advisory Opinion No. 110/2012, instituted by the Socio-Economic and Accountability Project (SERAP), African Court of Justice and Human Rights, 'Advisory Proceedings' <http:/www.african-court.org/en/index.php/cases/2016-10-17-16-1935\#finalised-opinions $>$ Accessed 29 November, 2019

${ }^{3}$ S. O. Nnamani, 'Institutional Mechanisms for Human Rights Protection in Nigeria: An Appraisal' [2011] 2 Journal of International Law and Jurisprudence, 128-137.

4 A. Ephraim, 'The Justice Eso Truth and Reconciliation Commission Report in Rivers State: Matters Arising' $<$ http://nigeriavillagesquare.com/forum/threads/the-justice-eso-truth-and-reconciliation-commission-report-in-rivers-state-matters-

arising.30535/> Accessed 29 November, 2019; Sahara Reporters, 'Rivers State Gov. Wike Establishes Commission to Investigate Re-run Election Violence' <http://saharareporters.com/2016/12/22/rivers-state-gov-wike-establishes-commission-investigate-re-run-electionviolence> Accessed 29 November, 2019; Rives State Commissions of Inquiry Law, Cap 30, Laws of Rivers State of Nigeria, 1999.

${ }^{5}$ O. W. Igwe and C. T. Emejuru, 'Appraising the Jurisprudence of the African Commission on Human and Peoples' Rights from 1995-2000 with Respect to the ESC and Solidarity Rights and its Legal Impact on the Status of Human Rights in Nigeria [2014] 4 (4) International Journal of Business, Humanities and Technology, 155-162.

${ }^{6}$ Ibid, 161-162.

${ }^{7} \mathrm{Ibid}, 162$.

${ }^{8}$ Ibid; B. Manby, The Price of Oil: Corporate Responsibility and Human Rights Violations in Nigeria's Oil Producing Communities (Human Rights Watch 1999) 176.
} 
Besides, even with the robust provisions of the ACHPR (Ratification and Enforcement) Act relating to the duties of government inherent in PSNWR, due to the hierarchical nature of the application and enforcement of domestic laws in Nigeria, this Act is a subsidiary law to the CFRN. ${ }^{1}$ In that case, as already indicated in the preceding study, other relevant provisions of the 1999 CFRN (as amended) would prevail instead of those of the ACHPR (Ratification and Enforcement) Act. ${ }^{2}$ On the whole, the prospects for the growth and advancement of the promotion, protection and enforcement of human rights are weak and thus not encouraging as compared to the state of affairs in advanced jurisdictions of the globe, mainly because human rights are consistently, systematically and colossally being abused and violated by African leaders, especially African political leaders, including those of Nigeria. ${ }^{3}$

Apart from the African Charter system's African Commission and African Court, as institutional frameworks of the ACHPR, in the preceding study to this work also discusses the National Human Rights Commission of Nigeria (NHRCN), which was established by the National Human Rights Commission (NHRC) Act, 1995, as amended by the NHRC Act, 2010, ${ }^{4}$ in compliance with the Resolution of the UNGA, which enjoins all UN member-states to establish national human rights institutions to promote, protect and enforce human rights in each UN member-state. Consequently, the NHRCN exists in the Thirty Six States of the FRN and the Federal Capital Territory (FCT), Abuja.

\subsubsection{Beyond the Realms of the African Charter System: The Ongoing Trend of Globalisation and the International Criminal Court (ICC)}

Beyond the realms of the African Charter system on human rights, being promoted, protected and enforced by the African Commission and the African Court, following ongoing and increasingly all-encompassing trend of globalisation, the International Criminal Court (ICC) may strengthen its positive global impacts by exercising greater jurisdiction over bad governance in African and other developing countries, as bad governments in developing countries are perpetrating human rights abuses and violations, and their associated crimes against humanity ${ }^{5}$ and cases of genocide ${ }^{6}$ in these countries. By so doing, the ICC would further discourage bad governance and human rights abuses and violations being occasioned in developing countries, and thereby contribute more meaningfully to their development and advancement, constructive nation-building ${ }^{7}$ and overall public good, in the course of ongoing and increasingly advancing worldwide efforts, championed by the UN, to achieve sustainable development (SD) around the globe, in the overall interest of humanity and society at large. This is more so, considering that the promotion, protection and enforcement of human rights constitute a onestop solution to every other problem, challenge or problematic issue in life confronting humanity, which include issues of the environment and development, particularly those of extractive industrial operations (EIOs) such as petroleum resources development operations in the oil-rich Delta region of Nigeria.

\subsubsection{The Nigeria Extractive Industries Transparency Initiative (NEITI) as the Institutional Framework of the NEITI Act}

Among other things, NEITI, as the institutional framework of the NEITI Act, is to ensure government's accountable, transparent and prudent management of the revenues accruing from EIOs such as oil and gas and other mineral resources development operations in Nigeria. However, governments, particularly the executive arm of government at the federal, state and local government levels in Nigeria, are still improperly managing the moneys accruing to them from EIOs, even when these operations, especially petroleum resources development operations are the mainstay of the political economy of the country. ${ }^{8}$ There is thus a need to implement

${ }^{1}$ Section 1 (3), 1999 CFRN (as amended); AG (Federation) v AG (Abia State) \& 35 Ors (No. 2) [2002] 6 NWLR. (Pt. 764), 542-905, [2002] 6 Judgements of the Supreme Court of Nigeria (MJSC) 1 SC;AG Bendel State $v$ AG Federation \& 22 Ors (1982) 3 NCLR 1 SC; per Kayode Eso JSC in Kalu v Odili [1992] 5 NWLR (Pt. 240) 130 at 188 SC; E. Malemi (n6) 61-67.

${ }^{2}$ Ibid; K. S. A. Ebeku, 'Constitutional Right to a Healthy Environment and Human Rights Approaches to Environmental Protection in Nigeria: Gbemre v. Shell Revisited' [2007] 16 (3) Review of European Community and International Environmental Law (RECIEL), 320; M. Clegg et al, THE HIERARCHY OF LAWS Understanding and Implementing the Legal Frameworks that Govern Elections (International Foundation for Electoral Systems 2016).

${ }^{3}$ U. O. Umozurike, The African Charter on Human and Peoples'Rights (Martin Nijhoff Publishers 1997) especially 129.

${ }^{4}$ National Human Rights Commission (NHRC) Act, 1995, Cap N46 Laws of the Federation of Nigeria (LFN) 2004, as amended by the NHRC (Amendment) Act, 2010.

${ }^{5}$ Homepage of the International Criminal Court <https://www.icc-cpi.int/> Accessed 29 November, 2019; J. Meernik, 'The International Criminal Court and the Deterrence of Human Rights Atrocities' [2015] 17 (3) Civil Wars, 318-339; International Crimes Database (ICD), 'Crimes against Humanity'<http://www.internationalcrimesdatabase.org/Crimes/CrimesAgainstHumanity> Accessed 29 November, 2019.

${ }^{6}$ Platform London, 'The Ogoni Struggle' <https://platformlondon.org/background/the-ogoni-struggle/> Accessed 29 November, 2019; Platform London, 'The Life \& Death of Ken Saro-Wiwa: a history of the struggle for justice in the Niger Delta' $<$ http://remembersarowiwa.com/wp-content/uploads/life_death_ksw.pdf $>$ Accessed 29 November, 2019; B. Olaniyi, 'MOSOP to world leaders: avert genocide in Ogoni' $<$ https://thenationonlineng.net/mosop-world-leaders-avert-genocide-ogoni/> Accessed 29 November, 2019. ${ }^{7}$ German-Southeast Asian Center of Excellence for Public Policy and Good Governance (CPG) in Cooperation with the Embassy of the Federal Republic of Germany, Bangkok, 'The Protection of Human Rights through the International Criminal Court as a Contribution to Constitutionalization and Nation-Building' 21 - 23 January 2011, Four Seasons Hotel Bangkok' <http://www.cpg-online.de/2011/01/21/theprotection-of-human-rights-through-the-international-criminal-court-as-a-contribution-to-constitutionalization-and-nation-building/> Accessed 29 November, 2019.

8 A. Malden, 'Nigeria's Oil and Gas Revenues: Insights from New Company Disclosures' 
benchmarked global standards of transparency and accountability as well as other good corporate governance standards and practices of the EIOs sector in Nigeria, so as to enhance the advancement of the sector towards poverty reduction and SD in the country. ${ }^{1}$ The problems and/or challenges of the petroleum resources industrial development operations in Nigeria may also be addressed in the context of Nigeria's ongoing nearly two-decadelong petroleum industry reform programme, towards a new petroleum industry governance regime in the country. ${ }^{2}$ Certainly, as the transparency institutional framework of the NEITI Act, if the potentials of the NEITI are fully harnessed, ${ }^{3}$ same would substantially increase the revenue profile of Nigeria and help to reduce poverty as well as contribute to environmentally-sound and socially-equitable SD in the country.

\subsubsection{The Nigerian National Petroleum Corporation (NNPC) and the Department of Petroleum Resources (DPR) as Institutional Frameworks of the NNPC Act}

The preceding study to this work discusses the NNPC and DPR as institutional frameworks of the NNPC Act. ${ }^{4}$ This study would thus briefly consider the effectiveness or otherwise of these two institutional frameworks of the NNPC Act, in terms of being able to accomplish some duties of Nigeria embedded in PSNWR, consequent upon petroleum resources development in the country.

\subsubsection{The NNPC as an Institutional Framework of the NNPC Act}

The preceding study to this work cites the NNPC Act, which dissolved the Nigerian National Oil Corporation (NNOC), established the NNPC and empowered it to engage in all commercial activities relating to the petroleum industry and to enforce all regulatory measures associated with the general control of the petroleum sector through its Petroleum Inspectorate department (PID). Given that the PID of the NNPC exists in reality as the DPR, the Inspectorate's functions are performed by the DPR. ${ }^{5}$

The NNPC is established by the NNPC Act as Nigeria's state petroleum corporation, which is a commercial entity, operator as well as a regulator of the industry. The NNPC is thus expected to operate as a successful national petroleum company, as the petroleum and renewable (alternative) energy resources development companies of other sovereign states, such as Brazil's Petrobras, ${ }^{6}$ Norway's Equinor (former 'Statoil') ${ }^{7}$ and Malaysia's Petronas. ${ }^{8}$ This has however not been so because the NNPC has not been performing optimally to accomplish its duties enshrined in the NNPC Act, as well as in compliance with its mission and vision statements as well as its core values and its other operational strategies stated in the preceding work to this study.

If the NNPC is able to operate efficiently, it is capable of contributing (in conjunction with such other governmental institutions, agencies and parastatals, as the Energy Commission of Nigeria [ECN]) to guarantee security of supply of petroleum energy products to Nigerian citizens and residents of the country. For instance, the combined effects of certain relevant provisions of the Petroleum Act, and the duties of the NNPC and particularly the ECN, have the potential to contribute to energy security, by helping to guarantee the security of supply of energy resources' products, such as petroleum energy products in Nigeria, as a way of accomplishing GSR to Nigerian citizens and residents in the country. Relevant provisions of the Petroleum, NNPC and ECN Acts include Sections 4, 6 and 7 of the Petroleum Act, Sections 5 (h) and (i) and 6 (1) (c) (d) of the NNPC Act, and Sections 1 and 5 of the ECN Act. ${ }^{9}$ So far, although Nigeria is abundantly rich in petroleum resources, the country is poor and thus afflicted by or suffering from a type of the 'resource curse' and 'energy poverty', ${ }^{10}$ which may be called 'petroleum energy poverty'.

$<$ https://resourcegovernance.org/sites/default/files/documents/nigeria-oil-revenue.pdf $>$ Accessed 29 November, 2019.

${ }^{1}$ E. T. Bristol-Alagbariya, Participation in Petroleum Development: Towards Sustainable Community Development in the Niger Delta (Centre for Energy Petroleum \& Mineral Law \& Policy [CEPMLP]/Dundee University Press [DUP] 2010) 83-101, especially 100.

2 Deloitte Nigeria, 'Nigeria: Nigeria's Senate Passes the Petroleum Industry Governance Bill' $<$ http://www.mondaq.com/Nigeria/x/598858/Oil+Gas+Electricity/Nigerias+Senate+Passes+The+Petroleum+Industry+Governance+Bill $>$

Accessed 29 November, 2019; A. Adefulu, 'Unbundling the Petroleum Industry Governance Bill' $<$ http://www.odujinrinadefulu.com/content/unbundling-petroleum-industry-governance-bill $>$ Accessed 29 November, 2019.

${ }^{3}$ D. Adugbo, 'Transparency, good governance major problems in mining sector -NEITI' $<$ https://www.dailytrust.com.ng/transparency-goodgovernance-major-problems-in-mining-sector-neiti.html $>$ Accessed 29 November, 2019.

${ }^{4}$ NNPC Act, 1977, No 33 of 1977 (Cap 320, LFN 1990 and Cap N123 LFN 2004)

${ }^{5}$ Section 1, NNPC Act, captioned 'Establishment of the Nigerian National Petroleum Corporation'; Section 5, NNPC Act, entitled 'General Duties of the Corporation'; Section 6, NNPC Act, captioned 'Powers of the Corporation'; and Section 10, NNPC Act, entitled 'Petroleum Inspectorate'; G. Etikerentse, Nigerian Petroleum Law (Dredew Publishers 2014) 20-21, 60-124.

${ }^{6}$ Petrobras, 'About us'<http://www.petrobras.com.br/en/about-us/> Accessed 29 November, 2019

${ }^{7}$ Equinor, 'About us'<https://www.equinor.com/en/about-us.html\#statoil-at-a-glance> Accessed 29 November, 2019.

${ }^{8}$ Petronas, 'About us' < https://www.petronas.com/about-us $>$ and $<$ https://www.petronas.com/about-us/overview $>$ Accessed 29 November, 2019.

${ }^{9}$ Section 4, Petroleum Act, 1969 (Cap 350 LFN 1990, now Cap P10, LFN 2004), captioned 'Control of Petroleum Products'; Section 6, Petroleum Act, entitled 'Price Control', and Section 7, Petroleum Act, headed 'Rights of Pre-emption'; Section 5, NNPC Act, captioned 'General Duties of the Corporation' and Section 6, NNPC Act, entitled 'Powers of the Corporation'; Section 1, ECN Act, No. 62 of 1979 (Cap E10, LFN 2004), captioned 'Establishment of the Energy Commission of Nigeria', and Section 5 of this Act, captioned 'Functions of the Commission'; S. C. Dike, Energy Security: The Case of Nigeria and Lessons from Brazil, Norway and the UK (Pearl Publishers 2015) 74-123, especially 120-123.

${ }^{10}$ A. Adenikinju et al (eds), Energy Resource Management in a Federal System (The Nigerian Association of Energy Economics 2014) 538561. 
The ongoing but protracted Nigerian petroleum industry reform process, which is designed to generate a new and better legal regime and its accompanying regulatory frameworks to govern the petroleum industry, ${ }^{1}$ is also expected to give birth to a new national petroleum energy company, which may operate effectively, in place of the NNPC. ${ }^{2}$

\subsubsection{The DPR as another Institutional Framework of the NNPC Act}

The preceding work to this study and the foregoing sub-heading have already mentioned that the DPR is the regulator of Nigeria's petroleum industry, existing in place of the 'Petroleum Inspectorate' department (PID) specified in Section 10 of the NNPC Act. The preceding work discusses the historical evolution of the DPR and its functions, as well as its operational guidelines, policies, standards, procedures and licences, permits, authorisations and practices, which are designed to govern the Nigerian petroleum industry and thus petroleum operations in the country. For instance, in the course of performing its roles and responsibilities, the DPR in 2018 issued about twenty-five (25) licences for the operation of modular refineries, otherwise called 'local refineries', in the oil-rich communities of the Niger Delta region, so as to, among other reasons, support existing petroleum refineries in Port Harcourt, Warri and Kaduna, and to enhance security of supply of petroleum products. ${ }^{3}$ Although, there are certain problems and challenges associated with the emergent regime of modular refineries, properly licensed, operated and regulated regime of modular refineries is in the overall interest of Nigeria, in the course of petroleum development in the country. ${ }^{4}$

It may therefore be pertinent to proceed further, in terms of examining DPR's performance of its functions, to state that government regulatory agencies in Nigeria are characterised by being command and control in form. It has been identified that there are problems militating against the command and control form of government regulatory agencies regulating EIOs, especially petroleum resources development operations, as such a regulatory form prevails against public interest. ${ }^{5}$ Some peculiar problems and/or challenges bedevilling government extractive industrial regulatory agencies in Nigeria include the prevalence of such factors as red-tape bureaucracy, over-regulation and regulatory capture, which distinguish these agencies from those of advanced countries like the United States of America and the United Kingdom. Regulatory capture takes place where regulatory failure arises when government regulatory agencies conform to the often overbearing and self-centred concerns, influence and interests of dominant industry players, such as the multinational oil and gas companies (MNOCs, also called Trans-National Oil and Gas Companies [TNOCs] or International Oil Companies [IOCs]), contrary to the dictates of good or benchmarked international environmental governance regulatory measures. Regulatory capture is often occasioned contrary to due process, public interest, and genuine interests of directly affected members of the public, like citizens of host oil-rich communities of the Delta region, who are adversely affected by oil and gas development operations in their communities.6 There is thus a need for government regulatory agencies in Nigeria to effectively perform their functions in a manner that promotes public interest. Government regulatory agencies in Nigeria should do so, in the course of regulating EIOs, especially the petroleum industrial sector, in the country. Besides, it may be reiterated that there is a need for government regulatory agencies of EIOs, particularly petroleum development operations, in Nigeria to be professionally resourceful, financially equipped, independent and efficient.7

Nigeria's DPR is obviously not an independent petroleum regulatory agency, due to undue influence being occasioned on it by the FG and its functionaries, and the MNOCs operating in the country. 8 Also, the degree of efficiency of the DPR is being adversely affected by the existence of other government regulatory agencies, which also regulate aspects of petroleum industrial operations and thus engendering regulatory bottle-necks in

\footnotetext{
${ }^{1}$ Petroleum Industry Governance Act (PIGA), 2018; Petroleum Industry Fiscal Bill (PIFB), 2018; Petroleum Host \& Impacted Communities Development Bill (PHICDB), 2018.

2 NNPC, 'FG Moves to Unbundle $\quad$ NNPC 30 into $<$ https://www.nnpcgroup.com/PublicRelations/NNPCinthenews/tabid/92/articleType/ArticleView/articleId/625/FG-Moves-to-Unbundle-

NNPC-into-30-Companies.aspx $>$ Accessed 29 November, 2019.

${ }^{3}$ E. Ejoh, 'DPR Issues 25 Licences for Modular Refineries' <https://www.vanguardngr.com/2018/05/dpr-issues-25-licences-modularrefineries/> Accessed 29 November, 2019; Detail Commercial Solicitors, 'Modular refineries: a short-term solution to boost Nigeria's energy needs and the naira' <http://www.financialnigeria.com/modular-refineries-a-short-term-solution-to-boost-nigeria-s-energy-needs-and-thenaira-sustainable-331.html $>\quad$ Accessed 29 November, 2019; I. Ifedobi, 'Benefits of Modular Refining' $<$ https://www.sunnewsonline.com/benefits-of-modular-refining/> Accessed 29 November, 2019.

${ }^{4}$ T. Ogbuigwe, 'Modular Refineries: Prospects and Challenges' $<$ https://guardian.ng/opinion/modular-refineries-prospects-and-challenges/> Accessed 29 November, 2019.

${ }^{5}$ E. O. Ekhator, 'Public Regulation of the Oil and Gas Industry in Nigeria: An Evaluation' [2016] 21 (1) Annual Survey of International and Comparative Law, 43-49.

${ }^{6}$ O. O. Oluwasanmi, 'Multinationals' Dominance and the Prospects for Development in the Nigerian Petroleum Industry' [2018] 5 (2) International Journal of Social and Management Sciences, 225-238.

${ }^{7}$ F. G. I. Inocencio, 'Independent Regulatory Agencies in the Oil and Gas Industry' [2018] 4 International Energy Law Review (IELR), 136146; E. T. Bristol-Alagbariya, Petroleum Development \& the Environment in Rivers State Nigeria: Fallouts of the UNEP Report on Ogoniland, Environmental Regulatory Standards \& Sustainable Development Laws \& Practices (LAP LAMBERT Academic Publishing 2018) 45; D. S. Olawuyi, Extractives Industry Law in Africa (Springer Nature Switzerland AG, 2018).

${ }^{8}$ E. O. Ekhator (n42) 43 and 89-91.
} 
the regulatory framework of the Nigerian petroleum industry. Such bottlenecks cut across regulatory agencies at the federal, states and local levels of government, whose functions interfere with those of the DPR. These government regulatory agencies include the EIA Department of the Federal Ministry of Environment (FMEnve), NESREA and NOSDRA as well as various state governments (SGs) and local governments (LGs) environmental protection and regulatory agencies. ${ }^{1}$

All in all, it is important that regulation of Nigerian petroleum industrial operations is fashioned after benchmarked standards and practices of the global petroleum sector so as to help to effectively regulate the sector in Nigeria and thereby vibrantly and robustly accomplish government's regulatory functions in the country. ${ }^{2}$ So far, based on the ongoing but protracted Nigerian petroleum industry reform, which is aimed at enacting three proposed laws, the proposed National Petroleum Regulatory Commission (NPRC) may become the regulatory agency of the industry that may replace the Petroleum Inspectorate (existing in reality as the DPR) and the Petroleum Products Pricing Regulatory Agency. The NPRC is to be responsible for regulating the entire petroleum industry, such that its functions will cut across the downstream, midstream and upstream sectors of the industry. If the proposed NPRC becomes the regulator of the Nigerian petroleum industry, the circumstances would then be appropriate and rational to consider if its mandate, composition and performances would qualify it as an independent and efficient regulator of the industry. ${ }^{3}$

\subsubsection{Performance of the Environmental Assessment (EA) Department of the Federal Ministry of Environment (FMEnve) and NESREA as Institutional Frameworks of the EIA Act}

No doubt, study antecedent to this study has identified the EA Department of the FMEnve and NESREA as institutional frameworks of the EIA Act. The preceding study identifies the EIA Department of the FMEnve, by or through which the FMEnve executes EIA certification and other administrative roles and responsibilities of the EIA process and practice at the level of federal government of Nigeria.

The EA Department is one of the technical departments established in the FMEnve at the inception of the Ministry in 1999. This Department is charged with the responsibility of ensuring that all developmental projects are executed in compliance with relevant environmental laws and regulations, so as to ensure sustainability of the environment in Nigeria. ${ }^{4}$ The Department's main functions are to: (a) implement the provisions of the EIA Act on development projects; (b) ensure environmental sustainability of development projects through regulation of activities within the oil and gas, mining, infrastructure, agriculture, manufacturing sectors, etcetera; (c) develop guidelines and standards for environmental quality monitoring, eco-labelling, etcetera; (d) accredit environmental laboratories; and (e) implement environmental audit and environmental management system (EMS). ${ }^{5}$ Consequently, the Department has four divisions. These are (a) Oil and Gas Division, (b) EIA Division, (c) Environmental Standard and Monitoring Division, and (d) Mining Environmental Assessment Division. ${ }^{6}$

It may be recalled that by virtue of its responsibilities, the defunct FEPA (now replaced by NESREA) published several materials on the protection and development of the environmental in Nigeria. These include Nigeria's National Policy on the Environment ${ }^{7}$ and Nigeria's National Agenda $21 .{ }^{8}$ Concerning EIA, the Federal Environmental Protection Agency (FEPA) published EIA procedural guidelines and EIA sectoral guidelines for all sectors of the Nigerian economy, as well as guidelines such as the National Guidelines on EMS in Nigeria and the National Guidelines on Environmental Audit in Nigeria. ${ }^{9}$ Besides, FEPA brought out publications on the Nigerian Petroleum industry and the environment. ${ }^{10}$ Eventually, after the creation of the FMEnve in 1999, the EIA Division of the FMEnve continued to publish and republish the foregoing EIA procedural guidelines,

\footnotetext{
${ }^{1}$ Section 20, 1999 CFRN (as amended), captioned 'Environmental Objectives'; Helios Towers Nig. Ltd. v National Environmental Standards and Regulations Enforcement Agency (NESREA) \& Anor, Suit No. FHC/KD/CS/65/2009 and Appeal No. CA/K/123/2010 (Unreported); Rivers State Government, 'Ministry of Environment' <http://beta.riversstate.gov.ng/mda/ministry-of-environment/> Accessed 29 November, 2019.

${ }^{2}$ J. Schneider et al, 'Towards Sustainability in the Oil and Gas Sector: Benchmarking of Environmental, Health, and Safety Efforts' [2013] 3 (3) Journal of Environmental Sustainability, 103-117; The UN Development Programme (UNDP), 'Our Focus: Sustainable Development: Extractive Industries' <https:/www.undp.org/content/undp/en/home/sustainable-development/environment-and-natural-capital/extractiveindustries.html $>$ Accessed 29 November, 2019.

${ }^{3}$ Part III, Sections 4-35, Petroleum Industry Governance Act (PIGA), 2018, captioned 'Nigeria Petroleum Regulatory Commission'; G. Bada, ' 5 things we know about the Petroleum Industry Bill' < https://www.pulse.ng/bi/politics/politics-5-things-we-know-about-the-petroleumindustry-bill/f0xbx5h> Accessed 29 November, 2019.

${ }^{4}$ FMEnve, 'Federal Ministry of Environment: Office of Environmental Assessment Department' < https://ead.gov.ng/> Accessed 29 November, 2019.

${ }^{5}$ FMEnve, 'Functions of the Department'<https://ead.gov.ng/about-us/> Accessed 29 November, 2019.

${ }^{6}$ FMEnve, 'Federal Ministry of Environment: Office of Environmental Assessment Department' (n49).

${ }^{7}$ FEPA, National Policy on the Environment (FEPA 1999).

${ }^{8}$ FEPA, Nigeria's National Agenda 21 (FEPA 1999).

${ }^{9}$ FEPA, Environmental Impact Assessment Procedural Guidelines (FEPA 1995); FEPA, Environmental Impact Assessment Sectoral Guidelines: Manufacturing Industries (FEPA 1995); FEPA, National Guidelines for Environmental Management System in Nigeria (FEPA 1999); FEPA, National Guidelines for Environmental Audit in Nigeria (FEPA 1999).

${ }^{10}$ E. O. A. Aina and N. O. Adedipe (eds), The Petroleum Industry and the Environmental Impact in Nigeria (FEPA 1996).
} 
sectoral guidelines and other environmental protection and environmentally-related development publications ${ }^{1}$ earlier published by the defunct FEPA as well as new ones in conformity with emerging realities in the realm of the relationship of the environment to development, towards SD. Also, through the EA Department of the FMEnve, the FG prepared and submitted an Executive Bill to Nigeria's $8^{\text {th }}$ National Assembly (June 9, 2015 June 9, 2019), captioned 'A Bill for an Act to Repeal the Environmental Impact Assessment Act, Cap E12 Laws of the Federation of Nigeria (LFN) 2004, and for other Related Matters', dated 16 October, 2018, ${ }^{2}$ for consideration. This Bill sought to upgrade the ongoing EIA process in Nigeria, by providing for Strategic Environmental Assessment (SEA) ${ }^{3}$ of PPPs in the country. So far therefore, the EA Department of the FMEnve may be described as making enormous efforts to positively intervene in the environmental governance of Nigeria, as it ensures that all developmental projects are carried out in compliance with relevant environmental laws and regulatory standards and practices, so as to ensure sustainability of the environment in the country. With greater political will and sustained pragmatic measures of the FG, it should be expected that the availability of adequate human and financial resources as well as the independence, dedication and effectiveness of the EA/EIA institutional regulatory organs such as the EA Department of the FMEnve and NESREA at the federal level of government, including the effectiveness of environmental protection agencies of SGs and EPAs of LGs in the federation as well as the active and unfettered involvement of resourceful EA and SEA consultants and organisations, the EA/EIA process and practice in Nigeria would significantly improve. ${ }^{4}$

Specifically concerning NESREA as a chief environmental policeman in Nigeria, the Agency is making efforts to positively intervene in environmental governance. NESREA is doing so, pursuant to its roles and responsibilities of environmental compliance monitoring and enforcement of all environmental laws, regulations, guidelines, standards, rules and policies in the country. ${ }^{5}$

As compared with the EIA Division of the FMEnve and NESREA in particular, it should be mentioned that the defunct FEPA was more professional, vigorous and independent in the discharge of its functions. This is more so, as NESREA and most especially the EA Department of the FMEnve are being slowed down in the performance of their functions by administrative encumbrances of the Nigerian civil service system.

\subsubsection{Effectiveness of NOSDRA as the Institutional Framework of the NOSDRA Act}

Again, the preceding study to this work has given a background of NOSDRA as the institutional framework of the NOSDRA Act. The previous study briefly outlines the roles and responsibilities of NOSDRA.

If efficiently responsible for surveillance and ensuring compliance with all existing environmental laws and regulations and detection of oil spills in the petroleum sector, NOSDRA would, no doubt, ensure timely and effective response to oil spills as well as proper clean-up, remediation and rehabilitation of all areas impacted by oil pollution during petroleum resources development operations in the oil producing communities of the Delta region. For NOSDRA to do so effectively, would mean ensuring that oil and gas companies, especially MNOCs, comply with existing national environmental laws and regulatory standards and practices, as increasingly being transformed by benchmarked international norms, standards, guidelines and practices on oil spills. ${ }^{6}$ Besides, in order to effectively perform its roles and responsibilities, NOSDRA should be able to streamline its functions and operations which overlap with those of other related government environmental regulatory agencies like the DPR (regulator of the petroleum industry) and the Nigerian Maritime Administration and Safety Agency (NIMASA [regulator of the maritime industry]). NIMASA regulates the maritime industry in Nigeria based on relevant statutory instruments, such as the NIMASA Act, 2007, the Merchant Shipping Act, 2007, and the Coastal and Inland Shipping (Cabotage) Act, 2003. ${ }^{7}$ The roles and responsibilities of NOSDRA involve to

\footnotetext{
${ }^{1}$ FMEnve, National Requirements and Guidelines on Environmental Management System in Nigeria (FMEnve 2009); FMEnve, Environmental Impact Assessment Sectoral Guidelines for Oil and Gas Industry Projects (FMEnve 2013); FMEnve, National Guidelines for Environmental Impact Assessment Act (Act 86. 1992): Post Impact Assessment (FMEnve 2013); FMEnve, National Guidelines for Environmental Impact Assessment Act (Act 86. 1992): Mining (FMEnve 2013); FMEnve, Guidelines for Review of EIA Report (FMEnve 2013).

${ }^{2}$ National Assembly, A Bill for an Act to Repeal the Environmental Impact Assessment Act, Cap. E12 Laws of the Federation of Nigeria (LFN) 2004 (National Assembly Press 2018); L. Cosmas, 'Reps C'tte Hold Public Hearing on Environmental Assessment Act' $<$ https://aljazirahnews.com/reps-ctte-hold-public-hearing-environmental-assessment-act/> Accessed 29 November, 2019.

${ }^{3}$ Section 61 of the proposed 'Bill for an Act to Repeal the Environmental Impact Assessment Act, Cap E12 Laws of the Federation of Nigeria (LFN) 2004', captioned 'Strategic Environmental Assessment (SEA)'; Section 62 of this Bill captioned 'Strategic Environmental Assessment Procedure'

${ }^{4}$ E. T. Bristol-Alagbariya (2018 [n44) 44, 49-50 and 53.

${ }^{5}$ N. S. Benebo, Appropriate Mechanisms for Environmental Protection and Sustainable Development in Nigeria: An Advocate's Viewpoint (NESREA 2014), 498-501.

${ }^{6}$ Vanguard newspaper, 'NOSDRA: Challenges of cleaning oil spills' $<$ https://www.vanguardngr.com/2011/10/nosdra-challenges-of-cleaningoil-spills/> Accessed 29 November, , 2019; E. Yafugborhi, 'Nigeria lags behind in response to oil spill —NOSDRA' $<$ https://www.vanguardngr.com/2018/04/nigeria-lags-behind-response-oil-spill-nosdra/> Accessed 29 November, 2019; S. O'neil, 'NOSDRA only effective on paper, says activist' < http://thenationonlineng.net/nosdra-only-effective-on-paper-says-activist/> Accessed 29 November, 2019

${ }^{7}$ Coastal and Inland Shipping (Cabotage) Act, No. 5 LFN 2003.
} 
control and prevent marine pollution, which are also the responsibilities of NIMASA. ${ }^{1}$ It has been identified that one of the paramount issues hindering the effective discharge of the responsibilities of NOSDRA is lack of capacity, which is hindering the effective discharge of NOSDRA's responsibilities regarding clean-up, remediation and rehabilitation of oil pollution sites in the oil-rich Niger Delta region. ${ }^{2}$ Also, in spite of the existence of NOSDRA, incidents of oil pollution are on the increase in the oil-rich communities of the Delta region. $^{3}$

Given that NOSDRA is considered as not functioning effectively, a new Bill was initiated but not fully considered by Nigeria's $8^{\text {th }}$ National Assembly, to bring about an amendment of the NOSDRA Act. ${ }^{4}$ By and large, to effectively perform its roles and responsibilities, there is a need for NOSDRA to exist and function as an independent regulator, which is equipped with requisite human and financial resources, and it should also be efficient in terms of service delivery.

\subsubsection{Performance of the FMEnve as an Umbrella Institutional Framework of NOSDRA, NESREA and EIA Acts}

The prior study to this work has already pointed out that NESREA and NOSDRA are agencies of the FG as well as parastatals of the FMEnve. So, the FMEnve may be described as an umbrella institutional framework of the NOSDRA, NESREA and the EIA Acts. The previous study also points out that in Nigeria's federal civil service system, the FMEnve superintends over the development and protection of the natural environment against pollution and degradation as well as biodiversity conservation and SD of Nigeria's natural resources and overall nature, so as to achieve the environmental objectives of the country enshrined in Section 20 of the 1999 CFRN (as amended), ${ }^{5}$ and to implement developmental PPPs and subsidiary laws made pursuant to this Section of the Constitution, as well as to achieve the UNSD Goals (UNSDGs) in the country.

The problems of the FMEnve are basically environmental problems, which range from various forms of pollution, such as oil pollution ${ }^{6}$ and gas flaring, ${ }^{7}$ deforestation to unsustainable production and consumption patterns. ${ }^{8}$ Environmental degradation and despoliation occasion greenhouse gas (GHG) emission ${ }^{9}$ and thus climate change in Nigeria, particularly in the course of petroleum development operations in the oil-rich Delta region.

Also, the problems of Nigeria's federal civil service system in terms of administrative encumbrances and general delivery of governmental services ${ }^{10}$ to the citizenry and the country, particularly the system's administrative encumbrances, hamper the effective performance of the roles and responsibilities of the FMEnve.

\subsubsection{The Niger Delta Development Commission (NDDC) as the Institutional Framework of the NDDC} Act

The preceding work to this study discusses the NDDC as the institutional framework of the Niger-Delta Development Commission (Establishment) Act (NDDC Act), which is a FG agency that is specifically established to achieve the Government's objectives arising from petroleum resources development operations in the oil-rich communities of the Niger Delta region. The enormous responsibilities of the NDDC enshrined in the NDDC Act are to ensure sustainable physical and socio-economic development and advancement of the oil-rich communities of the Delta region and to protect, remediate and rehabilitate the environment in the region as well as the socio-economic empowerment of the people, so as to achieve SD, premised on overall wellbeing of the region.

Consequently, the NDDC has been embarking on developmental PPPs that have positively touched and are

\footnotetext{
${ }^{1}$ Section 22 (1) (i) NIMASA Act, 2007, on control and prevent marine pollution; Section 22, NIMASA Act, 2007, captioned 'Functions of the Agency'; Section 23, NIMASA Act, 2007, entitled 'Powers of the Agency'; Section 5, NOSDRA Act, 2006, headlined 'Objectives of the Agency'; Section 6, NOSDRA Act, 2006, captioned 'Functions of the Agency'; Section 7, NOSDRA Act, 2006, captioned 'Special Functions of the Agency'.

${ }^{2}$ E. Yafugborhi (n61).

${ }^{3}$ Reuters (London), 'Shell Sees Rise in Nigeria Oil Spills in 2018' <https://www.investing.com/news/commodities-news/shell-sees-rise-innigeria-oil-spills-in-2018-1825022> Accessed 29 November, 2019.

${ }^{4}$ C. C. Okeke, 'NOSDRA new bill will make oil companies obey law - Sir Idabor' <https://www.dailytrust.com.ng/nosdra-new-bill-willmake-oil-companies-obey-law-sir-idabor.html $>$ Accessed 29 November, 2019.

${ }^{5}$ Section 20, 1999 CFRN (as amended), captioned 'Environmental Objectives'.

${ }^{6}$ United Nations Environment Programme (UNEP), Environmental Assessment of Ogoniland (UNEP 2011); K. Oyende, Oil Pollution Law and Governance in Nigeria (Stirling-Horden Publishers 2017); O. Awoyemi, The Impact of Oil Pollution on the Environment of the Oil Producing Communities of Nigeria: A Critical Analysis of the Statutory and Regulatory Provisions in Nigeria (Independent Law Publishing 2014).

${ }^{7}$ U. Udok and E. B. Akpan, 'Gas Flaring in Nigeria: Problems and Prospects' [2017] 5 (1) Global Journal of Politics and Law Research, 1628 .

${ }^{8}$ UNEP (n68).

9 USA Environmental Protection Agency (EPA), 'Greenhouse Gas Emissions: Global Greenhouse Gas Emissions Data' $<$ https://www.epa.gov/ghgemissions/global-greenhouse-gas-emissions-data $>$ Accessed 29 November, 2019; E. T. Bristol-Alagbariya (2018 [44) 59; Goal 13, UNSDGs, captioned 'Climate Action'.

${ }^{10}$ Section 169, 1999 CFRN (as amended), captioned 'Establishment of Civil Service of the Federation'; E. Malemi, Administrative Law (Princeton Publishing Co. 2012), 457; S. A. Adedire, 'Re-Inventing Nigerian Civil Service for Effective Service Delivery in the $21^{\text {st }}$ Century' [2012] 4(1) Fountain Journal of Management and Social Sciences 104-118.
} 
still touching the lives of the people and communities of the oil-rich Delta region. It holds out itself to have executed over 8, 000 projects in the region, ${ }^{1}$ which spread into remote oil-rich communities and areas of the region. These include the provision of public utilities and other community development, empowerment, relief and rehabilitation projects and programmes, which include construction of roads, bridges, culverts and other forms of water ways as jetties; rural electrification and rural water projects; construction of drainage systems, canalisation of creeks and river dredging projects, shore reclamation and protection projects; building of schools and hospitals, as well as furnishing them; construction of community markets, eradication of water hyacinth scheme, and provision of health care $^{2}$ for the aged and needy in the region's oil-rich communities. Others are youth empowerment schemes such as scholarship awards, skills acquisition and other capacity building programmes and projects in areas such as the development of small and medium scale enterprises (SME) and entrepreneurial skills, including capacity building and development programmes and projects for youngsters, which include information and communications technology (ICT) training schemes; and educational and rehabilitation schemes for ex-militant agitators of the Delta region. Yet, other NDDC developmental programmes and projects include the provision of fishing gears and farming implements, tools and equipment for rural artisanal fisher-folks and farmers. There are also such other developmental programmes and projects as educational grants and educational endowments to tertiary institutions, ${ }^{3}$ support for scholarly researches, and publishing of books and support of book launch programmes, in order to boost educational institutions in the Delta region and research and development $(\mathrm{R} \& \mathrm{D})$ for citizens of the region, who are engaged in the knowledge industry.

The NDDC may thus be considered as an agency of the FG, which is struggling to accomplish its wide and politically challenging mandate and statutory responsibilities to develop the oil-rich Delta region and the rest of the oil producing areas, which are all regarded as parts and parcels of the oil-rich Niger Delta region, by virtue of the provisions of the NDDC Act. ${ }^{4}$ The NDDC is however consistently being saddled with undue and sometimes overwhelming political interferences ${ }^{5}$ from the FG and its functionaries; more so, due to bad governance, ${ }^{6}$ which prevents the NDDC from being properly focused and committed to accomplishing its peculiar mandate and responsibilities to the people and oil-rich communities of the Delta region.

2.3.8 Effectiveness of the Nigerian Content Development Monitoring Board (NCDMB) as the Institutional Framework of the Nigerian Oil and Gas Industry Content Development Act (NOGICDA)

The study antecedent to this work discusses the Nigerian Oil and Gas Industry Content Development Act (NOGICDA), 2010. The previous study deliberates on the Nigerian Content Development Monitoring Board (NCDMB) as the institutional framework of the NOGICDA. It outlines the responsibilities of the Board to guide, monitor, coordinate and implement the provisions of the NOGICDA. ${ }^{7}$

The NCDMB is assiduously making efforts to build local capacities in the Nigerian oil and gas industrial sector, by monitoring companies operating in the sector and evaluating the compliance of these companies in conformity with set objectives and goals. ${ }^{8}$ By so doing, the Board has, among other strategies, developed some operational guidelines in order to enhance its operational activities. ${ }^{9}$ Also, it has since 2017 commenced publication of a local content quarterly digest magazine, ${ }^{10}$ to disseminate information and to enhance its interactive strategy with its stakeholders, especially oil and gas companies operating in the country, and the citizenry. Furthermore, the NCDMB is enquiring into new ways and means of maximising investments in the

\footnotetext{
${ }^{1}$ NDDC, 'Search Over 8,000 Projects in the Niger Delta Area!'<http://nddcproject.nddc.gov.ng/> Accessed 29 November, 2019.

${ }^{2}$ NDDC, 'NDDC Kicks Off Free Healthcare Programme in Niger Delta'<http://www.nddc.gov.ng/news_id6v.html > Accessed 29 November, 2019.

3 NDDC, 'Images for NDDC educational in tertiary Institutions' $<$ https://www.google.com/search?q=NDDC+educational+endowments + in + tertiary + institutions \&tbm $=$ isch \&source $=$ univ\&sa $=X$ \&ved=2ahUKEwjkp92x3qnhAhWVVBUIHTWNAqoQsAR6BAgJEAE\&biw=1920\&bih=969> Accessed 29 November, 2019.

${ }^{4}$ Section 1 (2) (b), Niger-Delta Development Commission (Establishment) (NDDC) Act, No. 6 LFN 2000, Cap N86 LFN 2004; Section 1, NDDC Act, captioned 'Establishment of the Niger-Delta Development Commission'; Section 4 of the Act, captioned 'Rotation of Office of Chairman of the Commission'.

${ }^{5}$ M. Jamison and A. Castaneda, 'Addressing Improper Political Interference - How can persons performing regulatory functions or developing regulatory instruments protect their work from improper political interference while, at the same time, maintaining accountability to the political wishes of the population?' $<$ http://regulationbodyofknowledge.org/faq/low-income-fragile-and-low-capacity-countries/howcan-persons-performing-regulatory-functions-or-developing-regulatory-instruments-protect-their-work-from-improper-political-interferencewhile-at-the-same-time-maintaining-accountability-to-the/> Accessed 29 November, 2019.

${ }^{6}$ R. Rose and C. Peiffer, Bad Governance and Corruption: Political Corruption and Governance (Palgrave Macmillan 2019), especially xiii; A. Mungiu-Pippidi, The Quest for Good Governance: How Societies Develop Control of Corruption (Cambridge University Press 2015); D. E. Agbiboa and B. Maiangwa, 'Corruption in the Underdevelopment of the Niger Delta in Nigeria' [2015] 5 (6) International Journal of Humanities and Social Science, 108-132.

${ }^{7}$ Section 4, Nigerian Oil and Gas Industry Content Development Act (NOGICDA), 2000, captioned 'Role of Nigerian Content Monitoring Board'.

8 ' $Q 1$ \&CDMB, \& $\quad$ Q2 $\quad$ Nigerian $\quad$ Content $<$ https://www.ncdmb.gov.ng/images/ComplianceMatrix/Q1\&Q22018CompaniesComplianceMatrix.pdf>Accessed 29 November, 2019.

${ }_{9}$ NCDMB, 'NCDMB Operational Guidelines'<https://ncdmb.gov.ng/operational-guidelines/> Accessed 29 November, 2019.

${ }^{10}$ NCDMB, 'Local Content Digest Magazine'<https://ncdmb.gov.ng/media/local-content-digest-magazine/> Accessed 29 November, 2019.
} 
Nigerian oil and gas industry for the benefit of Nigerian citizens and Nigerian indigenous companies operating in the industry, so as to improve the wellbeing of Nigerians in the Nigerian political economy. ${ }^{1}$

The NCDMB is however being confronted with certain problems. One of such problems is that local content in the Nigerian oil and gas industrial sector, which is the main sector of the political economy of Nigeria (Africa's foremost, about sixth largest oil producing and enormously gas resourceful country), is still low because of the decline of global oil price. ${ }^{2}$ Also, several services associated with the sector's value chain, such as basic engineering services, are still being rendered by oil and gas companies operating in Nigeria, but having foreign beneficial affiliations. ${ }^{3}$ For instance, fabrication of some plants, equipment and other support facilities utilised for oil and gas operations are still being designed and manufactured overseas and merely assembled in Nigeria, contrary to relevant provisions of the NOGICDA, such as Section 54 of the Act. ${ }^{4}$ The adverse effects of this state of affairs include lack of employment and absence of capacity-building opportunities for Nigerian citizens and Nigerian indigenous oil and gas companies operating in the country's petroleum industrial sector. ${ }^{5}$ Likewise, concerning Nigeria's (domestic) guidelines for the employment or engagement of expatriates in Nigerian oil and gas industrial sector, based on approved expatriate quota, some companies, especially MNOCs, operating in the sector, are still in default. Such companies surreptitiously engage expatriates without necessary approvals. There is thus a need to strengthen the monitoring and enforcement powers of the NCDMB to effectively monitor cases of breach of the criteria concerning the engagement of expatriates, and the use of plants, equipment and other support facilities that are still being imported and merely assembled in Nigeria, by oil and gas companies operating in the country. ${ }^{6}$ There are certain provisions of NOGICDA, such as those of its Section 41(2), which may undermine indigenous participation and thereby circumvent its general objectives in favour of oil and gas companies that are partly owned by Nigerians and foreigners or foreign interest groups. Also, the penal sanctions, under the NOGICDA for non-compliance of erring oil and gas companies, are meagre and thus not sufficient to prevent breach. ${ }^{7}$ Hence, there is a need for the sanctions prescribed in the Act to be strengthened and aggravated by appropriate regulation, made by the Minister, in conformity with Section 40 (1) of the Act. ${ }^{8}$ Beside the provisions of Section 27 of the NOGICDA, requiring oil and gas operating companies to maintain an office in a community, where the operator has significant operations, ${ }^{9}$ and Section $28(2)^{10}$ of the Act, which requires oil and gas operating companies or oil and gas project promoter to maintain a reasonable number of personnel from areas that the company or promoter has significant operation, the NCDMB would do better by exploring more ways and means by which the NOGICDA may exceptionally benefit the oil-rich communities of the Delta region. Finally, it may be noted that although the NOGICDA was enacted in 2010, at a time that it was long overdue, to revolutionise the Nigerian oil and gas industrial sector in favour of Nigerian citizens and Nigerian indigenous companies, much is desired for the Act to accomplish through the NCDMB, so as to justify the continued relevance of the Board.

2.3.9 The Federation Account Allocation Committee and the Joint Local Government Account Allocation Committee as Institutional Frameworks of the Allocation of Revenue (Federation Account) Act and the Concerns of the Oil-rich Delta Region

The study preceding this work identifies the Federation Account Allocation Committee (FAAC) and the Joint Local Government Account Allocation Committee (JAAC) as institutional frameworks of the Allocation of Revenue (Federation Account) Act. That preceding study also outlines the functions of these two committees. The provisions of the Allocation of Revenue (Federation Account) Act on JAAC help to demonstrate that local governments are not mere appendages to state governments in the FRN.

Considering that several regions or zones of Nigeria have generated products, which were the main sources of the country's revenue before the era of petroleum development in the oil-rich Delta region, this aspect of the study would concentrate on Nigeria's previous revenue allocation formulas and the concerns of the oil-rich Delta

\footnotetext{
${ }^{1}$ NCDMB, 'Nigerian Oil and Gas Opportunity Fair (NOGOF), 4 - 5 April, 2019, Multipurpose Hall, NCDMB New Headquarters Building, Oxbow-Lake, Yenagoa, Bayelsa State' <https://ncdmb.gov.ng/> Accessed 29 November, 2019; Vanguard newspaper, 'Shell Leads IOCs in Local Content- NCDMB'<https://www.vanguardngr.com/2019/04/shell-leads-iocs-in-local-content-ncdmb/> Accessed 29 November, 2019. 2 NNPC, 'Oil Production' <https://www.nnpcgroup.com/NNPCBusiness/UpstreamVentures/OilProduction.aspx > Accessed 29 November, 2019; B. Udo, 'INTERVIEW: Why local content in Nigeria's oil, gas industry is low - Executive Secretary, NCDMB' $<$ https://www.premiumtimesng.com/news/headlines/229141-local-content-nigerias-oil-gas-industry-low-executive-secretary-ncdmb.html> Accessed 29 November, 2019.

${ }^{3}$ T. Falola et al (eds), Nigeria and the International Capitalist System (Lynne Rienner Publishers 1988).

${ }^{4}$ Section 54, NOGICDA, 2010, captioned 'Prohibition of importation of welded products.'

5 Y. Adeoye, 'Nigerian Content Act: Strengths, Weaknesses' <https://www.vanguardngr.com/2012/08/nigerian-content-act-strengthsweaknesses/> Accessed 29 November, 2019.

6 S.P.A. Ajibade, 'Review of the Nigerian Oil and Gas Industry Content Development Act 2010' $<$ http://www.spaajibade.com/resources/review-of-the-nigerian-oil-and-gas-industry-content-development-act-2010/> Accessed 29 November, 2019 .

${ }^{7}$ Section 41, NOGICDA, 2010, entitled 'Regulations for further growth of indigenous capacity'.

${ }^{8}$ Section 40, NOGICDA, 2010, captioned 'Regulations for Training'.

${ }^{9}$ Section 27, NOGICDA 2010, captioned 'Office in community of operation'.

${ }^{10}$ Section 28, NOGICDA, 2010, entitled 'First Consideration for Employment and Training'.
} 
region regarding the country's current revenue allocation formula. Given that petroleum development, having tremendous adverse effects, is the main source of Nigeria's revenues, the Delta region is craving for a revenue allocation formula that is predominantly based on the principle of derivation, as was the case in the Nigerian regional era or that Nigeria should practise true federalism, based on fiscal federalism. For instance, revenue allocation based on the principle of derivation in the ongoing era of petroleum development in the oil-rich Delta region, had continued to dwindle until it was at a time less than 1 per cent, before it became increased to the prevailing 13 per cent, by virtue of Section 162 (2) of the 1999 CFRN (as amended). ${ }^{1}$ Meanwhile, during the Nigerian regional era, when the majority ethnic groups produced the resources of Nigeria such as groundnut from Northern Nigeria and cocoa from Western Nigeria (in other words when these two cash crops were the mainstay of Nigeria's economy), revenue allocation formula was in favour of the resources producing major ethnic groups. ${ }^{2}$ There have thus been and may well continue to be frequent yearnings of the people, communities and other citizen-groups of the oil-rich Delta region as well as agitation of true federalists for the practice of true fiscal federalism in Nigeria, as a way to achieve a just and equitable revenue sharing formula towards the enthronement of peace and SD in the process of petroleum resources development in the country. ${ }^{3}$

Apart from the prevailing unfair, unjust and inequitable revenue allocation formula in the ongoing era of petroleum resources development operations, which operations have enormous adverse effects than the negative effects of the groundnut pyramids and cocoa boom periods, there are various other consequences of the resources development operations on the people, communities and environment of the oil-rich Delta region. Such adverse consequences include devastation of the environment and despoliation of the ecology, ecosystems and ecosystem services in the region, disruption and prevention of fishing and farming, as major traditional occupations of the oil producing communities, and thus the adverse effects of these operations on the livelihoods and wellbeing of the people and SD in the region.

Remarkably, the prevalence of natural law and its ethical principles, as well as the principle, law and development practice of environmental democracy and EA and generic IA process and practice, as indices of GSR embedded in GG, would mean that the people and oil producing communities of the Delta region should benefit more from petroleum resources development operations in the communities and the enormous revenues accruing from these resources development operations to Nigeria. ${ }^{4}$

\subsubsection{Performance of the Ministry of Niger Delta Affairs (MNDA) as an Institutional Framework for the Development of the Oil-rich Delta Region}

The work antecedent to this study describes the Ministry of Niger Delta Affairs (MNDA) as an institutional framework of the federal civil service system established by the FG, led by President Umaru Musa Yar'Adua, in September 2008, to cater for the development of the Delta region in the process of petroleum development operations in the oil-rich communities of the region. Consequently, through the MNDA, the FG is embarking on some developmental PPPs in the Delta region. Such development projects and programmes include the development of new towns, the construction of coastal roads and rail lines, as well as the dualisation of the EastWest road. Other projects and programmes proposed by the FG, led by President Umaru Musa Yar'Adua, to develop the Delta region and other coastal areas of Nigeria include a well-defined waterways transportation, to be embarked upon by the FG to cover the entire coastal communities of the country, so as to improve the wellbeing of coastal communities of Nigeria. However, decades after initiating these developmental projects and programmes, most of them (the projects and programmes) are yet to be implemented by the $\mathrm{FG},{ }^{5}$ even though some key philosophical concepts of governance are those of collaborative government', 'continuity in government', and 'socially responsible politics', which are associated with the performance or effective performance of the duties of Nigeria inherent in PSNWR, in the context of petroleum development in the country.

From the foregoing, the MNDA may be described as a robust institutional framework of the FG vis-à-vis Nigeria's federal civil service system, which is however like a toothless bull-dog that can only bark but not bite, as it is essentially incapable of accomplishing its mandate to develop the oil-rich but poverty stricken, politically marginalised, socio-economically neglected, and environmentally endangered Niger Delta region. ${ }^{6}$ Certainly, the

\footnotetext{
${ }^{1}$ Section 162, 1999 CFRN (as amended), captioned 'Distributable Pool Account'; Allocation of Revenue (Abolition of Dichotomy in the Application of the Principle of Derivation) Act, 2004

${ }^{2}$ E. T. Bristol-Alagbariya (2010 [n28]) 40-43 and 61; A. Ogbuigwe, Offended: Legal Issues in the Niger Delta Struggle (Anpez Centre for Environment and Development 1999) 19-20; S. Azaike, Inequities in Nigerian Politics (Treasure Communications Resource 2003); R. T. Suberu, Ethnic Minority Conflicts and Governance in Nigeria (Spectrum 2003).

${ }^{3}$ I. J. Elaigwu (ed), Fiscal Federalism in Nigeria: Facing the Challenges of the Future (Adonis \& Abbey Publishers 2008).

${ }^{4}$ B. C. Smith, Good Governance and Development (Palgrave Macmillan 2007).

${ }^{5}$ E. T. Bristol-Alagbariya, Governance Towards Sustainable Development in Nigeria: The Role of Strategic Assessment of Decisions \& Actions (CEPMLP/DUP 2013) 253-254.

${ }^{6}$ S. C. Izah, 'Ecosystem of the Niger Delta region of Nigeria: Potentials and Threats' [2018] 2 (4) Biodiversity International Journal, 338345; O. Adams, 'Niger Delta Ministry: Re-focusing for development' < https://www.vanguardngr.com/2016/02/niger-delta-ministry-refocusing-for-development/> Accessed 29 November, 2019.
} 
episode of a characteristically dormant, inherently ineffective and moribund MNDA evidences the abysmal degree of disconnection between institutions of government and the governed in Nigeria. ${ }^{1}$

\subsection{PSNWR: Duties of Governments to the Country, the Citizenry and the oil-rich Delta Region in the Course of Petroleum Development in the Region}

Obviously, there is absence of GSR in Nigeria, particularly so in the oil-rich minority ethnic Delta region. This means lack of performance or ineffective performance of the duties of government towards the overall wellbeing of the country and the oil-rich minority ethnic Delta region, in the process of petroleum development in the region in the ongoing era of $\mathrm{SD} .^{2}$

The duties of government, covering the roles and responsibilities of the Federal Government (FG), and those of various State Governments (SGs) and Local Governments (LGs) having jurisdiction over the Delta region and other oil producing areas of the country are being breached by the affected departments, tiers and institutions of government. In fact, the alarming degree of GSR (towards the citizens and other members of the public) in the country demonstrates that there is disconnection between government and by extension government functionaries and institutions on one hand and citizenry and other members of the public on the other. ${ }^{3}$ From the premise of various laws, policies, regulatory measures and practices in the country, government functionaries and institutions of government are, to a great extent, irresponsible in terms of catering for the security and wellbeing of the citizens and other members of the public in the county as embedded in the social contract of governance. The enormous degree of irresponsibility of government, comprised of government functionaries and government institutions and/or organisations, account for the prevailing wide magnitude of inequality between the rich and the poor in the country, and its resultant poverty and destitution, ${ }^{4}$ as well as the non-diversification of the country's economy, the fact that the country is not economically developed and not socio-economically advanced, ${ }^{5}$ over about six decades of petroleum development operations in its oil-rich Delta region. Such enormous degree of the absence of GSR demonstrates the absence of GG and thus the prevalence of bad governance in Nigeria. Consequently, although, Nigeria is abundantly rich in petroleum resources, the country is poor and thus afflicted by a peculiar type of the 'resource curse' and 'energy poverty', ${ }^{6}$ which may be called 'petroleum energy poverty'. Citizens of the oil-rich minority ethnic Delta region and other oil producing communities of Nigeria are also suffering from poverty and hunger in the midst of plenty, ${ }^{7}$ namely the plentiful wealth being generated by government from petroleum resources development operations in their communities. Although, the oil-rich Delta region, one of the world's largest wetlands and homeland of several minority ethnic nationalities, has by reason of its geographical location and petroleum resources occupied a strategic position in the formation, sustenance and survival of Nigeria, yet, it remains one of the least developed regions of the country; this epitomises one of the most pathetic paradoxes and contradictions of poverty in the midst of plenty. ${ }^{8}$ Also, the environment in the oil-rich communities of the Delta region is gravely being devastated, while the ecology, ecosystem and ecosystem services are despoiled, and thereby endangering natural resources and overall nature in the communities, without appropriate environmental protection, remediation and rehabilitation measures. ${ }^{9}$ In fact, the environment in the Delta region is being so gravely abused, degraded, devastated and despoiled that the region is regarded as about the most crisis-riven ${ }^{10}$ and endangered Delta region in the world. ${ }^{1}$

\footnotetext{
${ }^{1}$ E. T. Bristol-Alagbariya (2013 [n97] 251 and 261; D. Adeojo, 'Bridging the gap between the government and the governed' $<$ https://www.thecable.ng/bridging-gap-government-governed $>$ Accessed 29 November, 2019; B. Jennings, Ecological Governance toward a New Social Contract with the Earth (West Virginia University Press 2016).

${ }^{2}$ J. F. Sachs (n10).

${ }^{3}$ K. Nweke and J. O. Nkwede, 'The Nigerian State and Hobbes' Social Contract Theory: An Albatross around the Collective Will of the People' [2019] 152 (3) European Journal of Scientific Research, 304-321; G. A. Oguntade, 'The Social Contract: Which way Nigeria?' $<$ https://thenationonlineng.net/social-contract-way-nigeria/> Accessed 29 November, 2019; E. T. Bristol-Alagbariya (2013 [n97]) 251 and 261; McCombs School of Business, 'Social Contract Theory' $<$ https://ethicsunwrapped.utexas.edu/glossary/social-contract-theory $>$ Accessed 29 November, 2019.

${ }^{4}$ J. O. Ojeme, 'A Critical Appraisal of African Largest Economy Ravaged in Poverty \& Destitution (A Case Study of Nigeria in the Light of the Recent Rebasing Nigerian GDP)'[2017] 3 (2) International Institute of Academic Research and Development (IIARD), $29-52$.

${ }^{5}$ R. Hannesson, Investing for Sustainability: The Management of Mineral Wealth (Kluwer 2001).

${ }^{6}$ A. Adenikinju et al (eds) (n37).

${ }^{7}$ E. C. Onwuka, 'Oil Extraction, Environmental Degradation and Poverty in the Niger Delta Region of Nigeria' [2005] 62 (6) International Journal of Environmental Studies, 655-662; I. Gary and T. L. Karl, Bottom of the Barrel: Africa's Oil Boom and the Poor (Catholic Relief Services 2003)

${ }^{8}$ Department of Political Science, Niger Delta University, International Conference on The Nigerian State, Oil Industry and the Niger Delta, Conference Proceedings (Harey Publications Company 2008) 1.

${ }^{9}$ UNEP (n68); O. Ihunwo, 'Review of UNEP Report on the Environmental Assessment of Ogoniland: Environmental Economics and Resource Management in Water Policy Making \& Environmental Impact and Risk Assessment for the Society in Water and Coastal Management'

$<$ https://www.researchgate.net/publication/323015407 Review of UNEP Report on the Environmental Assessment of Ogoniland $>$ Accessed 29 November, 2019.

${ }^{10}$ I. Bannon and P. Collier (eds), Natural Resources and Violent Conflict: Options and Actions (The World Bank 2003); F. Allen, Implementation of Oil Related Environmental Policies in Nigeria: Government Inertia and Conflict in the Niger Delta (Cambridge Scholars
} 
Accordingly, human rights, ${ }^{2}$ especially environmental rights ${ }^{3}$ of citizens of the oil-rich minority ethnic Delta region and those of other oil producing communities of Nigeria are being incessantly abused and violated in the process petroleum development operations in the oil-rich communities of the country. Petroleum development operations have thus neither contributed much to the improvement of the overall wellbeing and quality of life of Nigerian citizens, nor have these operations contributed to the all-embracing development, advancement and prosperity of the country. ${ }^{4}$ All these and many other consequences of petroleum resources development operations in Nigeria and particularly the oil-rich Delta region are prevailing because of the failure of Nigeria, represented by governments, government officials and government institutions, to accomplish or effectively perform Nigeria's duties embedded in PSNWR, in the course of these resources development operations in the country.

Based on the theory of natural law, its divine roots, its association with morality ${ }^{5}$ and the concept of GG, ${ }^{6}$ which has such characteristic features as transparency and accountability, ${ }^{7}$ it may be argued that Nigerian citizens deserve good attention and better stewardship from their governments, in terms of securing their welfare and the wellbeing of the country, in the course of petroleum resources development in the oil-rich communities of the country. In the same vein, it may be contended that citizens of the oil-rich Delta region, including the environment in the region, deserve greater attention as well as reasonable stewardship in the course of these resources development operations in their region and other oil producing areas of the country.

\subsection{Conclusion}

Based on the rights and duties of global states, particularly resources-rich developing countries, inherent in PSNWR, this study has attempted to give an overview of PSNWR and examined the efficacy of some government institutions set-up on the basis of their enabling laws and overall GSR associated with petroleum development in Nigeria. From the threshold of the duties ingrained in PSNWR, the study examined the duties of Nigeria, represented by governments in the country, to the country, the citizenry and the oil-rich Delta region, in the course of petroleum development in the oil producing communities of the region.

Consequent upon the foregoing examinations, the study concludes that governments in Nigeria are in breach of the social contract of governance between government and the citizens, due to weak or ineffective GSR, which responsibility is basically same as the duties of Nigeria inherent in PSNWR, with particular regard to petroleum development in the country. Therefore, to realise outstanding GSR and to have efficient government institutions in Nigeria, we recommend that improved GSR, embedded in GG, should be the key driver of PPPs as well as laws, government institutions and overall process of nation-building, as such a qualitative standard of GSR would be able to generate appropriate domestication of benchmarked international SD-oriented standards and practices associated with PSNWR in the course of petroleum development in the country. Such a classic form of GSR should be able to promote the viability, vibrancy, dynamism and efficiency of government institutions, away from epilepticism or inherent ineffectiveness of these institutions, in the march to achieve SD in the country, via steady growth, advancement and all-embracing prosperity and wellbeing of the citizenry.

The need for outstanding GSR to enhance the achievement of SD in Nigeria, towards steady growth, advancement and all-embracing prosperity in the country and the wellbeing of the citizenry, is even more crucial. This is so, since the research that preceded this study has demonstrated that although soft law mechanisms are not legally binding obligations on parties such as global sovereign states, environmental protection and other SD-oriented soft law mechanisms are increasingly governing petroleum resources development operations and other EIOs such that these mechanisms are positively transforming domestic legal and institutional frameworks, standards and practices of resources-rich developing countries like Nigeria, in the ongoing era of SD.

\section{References}

Adedire S. A., 'Re-Inventing Nigerian Civil Service for Effective Service Delivery in the 21st Century' [2012] 4(1) Fountain Journal of Management and Social Sciences 104-118.

Adenikinju A., Iwayemi A. and Iledare W. (eds), Energy Resource Management in a Federal System (The

Publishing 2014).

${ }^{1}$ E. T. Bristol-Alagbariya , (2018 [n44) 32.

${ }^{2}$ B. Manby (n19).

${ }^{3}$ Jonah Gbemre $v$ The Shell Petroleum Development Company Nigeria Ltd \& 2 Ors [2005] (FHC/B/CS/53/05).

${ }^{4}$ J. A. Ajienka and I. Ibeji (eds), Petroleum and the Quality of Life (Institute of Petroleum Studies, University of Port Harcourt, 2004$), 1-2$.

${ }^{5}$ M. H. Kramer, Where Law and Morality Meet (Oxford University Press 2004).

${ }^{6}$ C. Stückelberger et al (eds), Global Ethics for Good Leadership: Values and Virtues for Life (Globethics.net 2016); E. T. Bristol-Alagbariya (2013 [n 97]) 42-46.

${ }^{7}$ M. Turner and D. Hulme, Governance, Administration \& Development: Making the State Work (Kumarian Press 1997) 229-231; E. T. Bristol-Alagbariya (2013 [n97)] 42; S. A. Usman, 'Senate moves to scrap government agencies, others' $<$ https://dailypost.ng/2019/09/26/senate-moves-scrap-government-agencies-others/> Accessed 29 November, 2019. 
Nigerian Association of Energy Economics 2014), 538-561.

Agbiboa D. E. and Maiangwa B., 'Corruption in the Underdevelopment of the Niger Delta in Nigeria' [2015] 5 (6) International Journal of Humanities and Social Science, 108-132.

Aina E. O. A. and Adedipe N. O. (eds), The Petroleum Industry and the Environmental Impact in Nigeria (FEPA 1996).

Ajienka J. A. and Ibeji I. (eds), Petroleum and the Quality of Life (Institute of Petroleum Studies, University of Port Harcourt, 2004), 1-2.

Allen F., Implementation of Oil Related Environmental Policies in Nigeria: Government Inertia and Conflict in the Niger Delta (Cambridge Scholars Publishing 2014)

Allen F., Implementation of Oil Related Environmental Policies in Nigeria: Government Inertia and Conflict in the Niger Delta (Cambridge Scholars Publishing 2014).

Awoyemi O., The Impact of Oil Pollution on the Environment of the Oil Producing Communities of Nigeria: A Critical Analysis of the Statutory and Regulatory Provisions in Nigeria (Independent Law Publishing 2014).

Azaike S., Inequities in Nigerian Politics (Treasure Communications Resource 2003).

Bannon I. and Collier P. (eds), Natural Resources and Violent Conflict: Options and Actions (The World Bank 2003).

Benebo N. S., Appropriate Mechanisms for Environmental Protection and Sustainable Development in Nigeria: An Advocate's Viewpoint (NESREA 2014), 498-501.

Bristol-Alagbariya E. T., Governance Towards Sustainable Development in Nigeria: The Role of Strategic Assessment of Decisions \& Actions (CEPMLP/DUP 2013), 42 - 46, 251, 253-254, 261.

Bristol-Alagbariya E. T., Participation in Petroleum Development: Towards Sustainable Community Development in the Niger Delta (Centre for Energy Petroleum \& Mineral Law \& Policy [CEPMLP]/Dundee University Press [DUP] 2010), 40 - 43, 61, 83-101, especially 100.

Bristol-Alagbariya E. T., Petroleum Development \& the Environment in Rivers State Nigeria: Fallouts of the UNEP Report on Ogoniland, Environmental Regulatory Standards \& Sustainable Development Laws \& Practices (LAP Lambert Academic Publishing 2018), 44-45, 49-50, 53, 59.

Cameron P. D. and Michael M. C., Oil, Gas, and Mining: A Sourcebook for Understanding the Extractive Industries (World Bank Group 2017).

Clegg M., Ellena K., Ennis D. and Vickery C., THE HIERARCHY OF LAWS Understanding and Implementing the Legal Frameworks that Govern Elections (International Foundation for Electoral Systems 2016).

Department of Political Science, Niger Delta University, International Conference on The Nigerian State, Oil Industry and the Niger Delta, Conference Proceedings (Harey Publications Company 2008) 1.

Dike S. C., Energy Security: The Case of Nigeria and Lessons from Brazil, Norway and the UK (Pearl Publishers 2015), 74-123, especially 120-123.

Ebeku K. S. A., 'Constitutional Right to a Healthy Environment and Human Rights Approaches to Environmental Protection in Nigeria: Gbemre v. Shell Revisited' [2007] 16 (3) Review of European Community and International Environmental Law (RECIEL), 312-320.

Ekhator E. O., 'Public Regulation of the Oil and Gas Industry in Nigeria: An Evaluation' [2016] 21 (1) Annual Survey of International and Comparative Law, 43, 89-91.

Elaigwu I. J. (ed), Fiscal Federalism in Nigeria: Facing the Challenges of the Future (Adonis \& Abbey Publishers 2008).

Etikerentse G., Nigerian Petroleum Law (Dredew Publishers 2014), 20-21, 60-124.

Falola T., Ihonvbere J. O. and Rienner L. (eds), Nigeria and the International Capitalist System (Lynne Rienner Publishers 1988).

Federal Environmental Protection Agency (FEPA), Environmental Impact Assessment Procedural Guidelines (FEPA 1995).

FEPA, Environmental Impact Assessment Sectoral Guidelines: Manufacturing Industries (FEPA 1995).

FEPA, National Guidelines for Environmental Management System in Nigeria (FEPA 1999).

FEPA, National Guidelines for Environmental Audit in Nigeria (FEPA 1999).

FMEnve, Environmental Impact Assessment Sectoral Guidelines for Oil and Gas Industry Projects (FMEnve 2013).

FMEnve, Guidelines for Review of EIA Report (FMEnve 2013).

FMEnve, National Guidelines for Environmental Impact Assessment Act (Act 86. 1992): Post Impact Assessment (FMEnve 2013).

FMEnve, National Requirements and Guidelines on Environmental Management System in Nigeria (FMEnve 2009).

Gary I. and Karl T. L., Bottom of the Barrel: Africa's Oil Boom and the Poor (Catholic Relief Services 2003).

Hannesson R., Investing for Sustainability: The Management of Mineral Wealth (Kluwer 2001).

Igwe O. W. and Emejuru C. T., 'Appraising the Jurisprudence of the African Commission on Human and 
Peoples' Rights from 1995-2000 with Respect to the ESC and Solidarity Rights and its Legal Impact on the Status of Human Rights in Nigeria' [2014] 4 (4) International Journal of Business, Humanities and Technology, 155-162.

Inocencio F. G. I., 'Independent Regulatory Agencies in the Oil and Gas Industry' [2018] 4 International Energy Law Review (IELR), 136-146.

Izah S. C., 'Ecosystem of the Niger Delta region of Nigeria: Potentials and Threats' [2018] 2 (4) Biodiversity International Journal, 338-345.

Jennings B., Ecological Governance toward a New Social Contract with the Earth (West Virginia University Press 2016).

Kramer M. H., Where Law and Morality Meet (Oxford University Press 2004).

Lyons D., 'The Correlativity of Rights and Duties' [1970] 4 (1) Nô̂s, 45-55.

Malemi E., The Nigerian Constitutional Law (Princeton Publishing Co. 2012), 61-67, 107-121.

Malemi E., Administrative Law (Princeton Publishing Co. 2012), 457

Manby B., The Price of Oil: Corporate Responsibility and Human Rights Violations in Nigeria's Oil Producing Communities (Human Rights Watch 1999), 176.

Meernik J., 'The International Criminal Court and the Deterrence of Human Rights Atrocities' [2015] 17 (3) Civil Wars, 318-339.

Mungiu-Pippidi A., The Quest for Good Governance: How Societies Develop Control of Corruption (Cambridge University Press 2015).

Nnamani S. O., 'Institutional Mechanisms for Human Rights Protection in Nigeria: An Appraisal' [2011] 2 Journal of International Law and Jurisprudence, 128-137.

Nweke K. and Nkwede J. O., 'The Nigerian State and Hobbes' Social Contract Theory: An Albatross around the Collective Will of the People' [2019] 152 (3) European Journal of Scientific Research, 304-321.

Ogbuigwe A., Offended: Legal Issues in the Niger Delta Struggle (Anpez Centre for Environment and Development 1999), 19-20.

Ogbuigwe A., Legal Issues in the Niger Delta resource Dilemma: A Collection of Essays (Anpez Centre for Environment and Development 2018).

Ojeme J. O., 'A Critical Appraisal of African Largest Economy Ravaged in Poverty \& Destitution (A Case Study of Nigeria in the Light of the Recent Rebasing Nigerian GDP)'[2017] 3 (2) International Institute of Academic Research and Development (IIARD), 29-52.

Okilo M., Art of Government and the Okilo Administration (Riverside Communications 1992), 1.

Okogbule N. S., Legal Status of Economic Development Agreements (Davis Printing \& Packaging Co. 2004)

Okogbule N. S., Globalisation and Human Rights in Africa (Sibon Books 2012) 217, 237.

Oluwasanmi O. O., 'Multinationals' Dominance and the Prospects for Development in the Nigerian Petroleum Industry’ [2018] 5 (2) International Journal of Social and Management Sciences, 225-238.

Olawuyi D. S., Extractives Industry Law in Africa (Springer Nature Switzerland AG 2018).

Olawuyi D. S., The Principles of Nigerian Environmental Law (Afe Babalola University Press 2015).

Oyende K., Oil Pollution Law and Governance in Nigeria (Stirling-Horden Publishers 2017).

Onwuka E. C., 'Oil Extraction, Environmental Degradation and Poverty in the Niger Delta Region of Nigeria' [2005] 62 (6) International Journal of Environmental Studies, 655-662.

Public Sector Group Poverty Reduction and Economic Management (PREM) Network, Reforming Public Institutions and Strengthening Governance (The International Bank for Reconstruction and Development [IBRD]/The World Bank 2000).

Rose R. and Peiffer C., Bad Governance and Corruption: Political Corruption and Governance (Palgrave Macmillan 2019), xiii.

Sachs J. F., The Age of Sustainable Development (University of Columbia Press 2015).

Samaha A. M., 'Undue Process' [2006] 59 (3) Stanford Law Review, 601, 672.

Schneider J., Ghettas S., Merdaci N., Brown M., Martyniuk J., Alshehri W. and Trojan A., 'Towards Sustainability in the Oil and Gas Sector: Benchmarking of Environmental, Health, and Safety Efforts' [2013] 3 (3) Journal of Environmental Sustainability, 103-117.

Schrijver N., Sovereignty over Natural Resources: Balancing Rights and Duties (Cambridge University Press 1997), 1-3.

Smith B. C., Good Governance and Development (Palgrave Macmillan 2007).

Stückelberger C., W. Fust and O. Ike (eds), Global Ethics for Good Leadership: Values and Virtues for Life (Globethics.net 2016).

Suberu R. T., Ethnic Minority Conflicts and Governance in Nigeria (Spectrum 2003).

Suberu R. T., Federalism and Ethnic Conflict in Nigeria (United States Institute of Peace 2001)

Terry H. T., 'Legal Duties and Rights' [1903] 12 (4) The Yale Law Journal, 185-212.

Turner M. and Hulme D., Governance, Administration \& Development: Making the State Work (Kumarian Press 
1997) 229-231.

Udofia I., Nigerian Constitutional Law: A Comparative Approach (Esquire Publishers 2018), 31-33.

Udok U. and Akpan E. B., 'Gas Flaring in Nigeria: Problems and Prospects' [2017] 5 (1) Global Journal of Politics and Law Research, 16-28.

Umozurike U. O., The African Charter on Human and Peoples' Rights (Martin Nijhoff Publishers 1997), 129.

United Nations Environment Programme (UNEP), Environmental Assessment of Ogoniland (UNEP 2011).

World Commission on Environment and Development (WCED), Our Common Future (Oxford University Press 1987). 